3

\title{
The relationship between benthic nutrient fluxes and bacterial community in Aquaculture Tail-water Treatment Systems
}

ABSTRACT Constructed-wetlands, Biofilms, and sedimentation are potential aquaculture tailwater treatments however their roles on the distribution of benthic microbial community and the way they affect the interaction between microbial community and inorganic nutrient fluxes have not been fully explored. This study applied $16 \mathrm{~S}$ rRNA high-throughput sequencing technology to investigate the microbial community distribution and their link with nutrient fluxes in an aquaculture tail-water bioremediation system. Results showed that bacterial community compositions were significantly different in constructed-wetland and biofilm treatments $(\mathrm{p}<0.05)$ relative to sedimentation. The composition of the 16S rRNA genes among all the treatments was enriched with Proteobacteria, Bacteroidetes, Firmicutes, and Flavobacteria. NMDS analysis showed that the bacterial composition in constructed-wetland and biofilm samples clustered separately compared to those in sedimentation. The Functional-Annotation-of-Prokaryotic-Taxa analysis indicated that the proportions of sediment-microbial-functional groups (aerobicchemoheterophy, chemoheterotrophy, and nitrate-ammonification combined) in the constructedwetland treatment were $47 \%, 32 \%$ in biofilm and $13 \%$ in sedimentation system. Benthic-nutrient fluxes for phosphate, ammonium, nitrite, nitrate and sediment oxygen consumption differed markedly among the treatments $(\mathrm{p}<0.05)$. Canonical correspondence analysis indicated constructed-wetland had the strongest association between biogeochemical contents and the bacterial community relative to other treatments. This study suggests that the microbial community distributions and their interactions nutrient fluxes were most improved in the constructed-wetland followed by the area under biofilm and sedimentation treatment. 
25 KEY WORDS: Sediment bacteria community; Tail-water; Biofilm; Constructed-wetland;

26 Nutrients; High throughout sequencing

27

28 Regan Nicholaus ${ }^{1,2}$, Betina Lukwambe ${ }^{1,3}$, Wen Yanga ${ }^{1}$, Zhongming Zhenga ${ }^{1 *}$

291 School of Marine Sciences, Ningbo University, Ningbo 315832, China

302 Department of Natural Sciences, Mbeya University of Science and Technology, Mbeya,

31 Tanzania

323 Department of Food Science and Technology, University of Dar as Salaam, Dar es Salaam,

33 Tanzania

34 *Corresponding author

35 Email: zhengzhongming@nbu.edu.cn,

36 Mailing address: Ningbo University at Meishan, 169 Qixingnan Rd, Beilun District, Ningbo,

$37 \quad 315832$ China

\section{Introduction}

Intensive aquaculture farming practices have contributed overwhelming allochthonous

41 organic matter (OM), excreta, food-wastes, and dissolved nutrients (e.g., nitrogen and

42 phosphorous) with substantial impacts on the environment [1-6]. The pollution increment within

43 the environment has increased the concern for the adoption of aquaculture effluent treatments.

44 Biological effluent treatments such as constructed wetland and biofilm and physical treatments

45 like sedimentation are highly used in treating aquaculture effluents [7-9].

Constructed-wetlands are artificially designed biological systems consisting of a complex

47 substrate, plants (macrophytes), microbes, and water bodies forming an ecosystem [10]. Besides 
48 they are a well-established, viable, suitable, and cost-effective method for treating various forms

49 of wastewater such as industrial and agricultural wastewaters [11]. Wetland plants

50 photosynthesize by their aboveground organs, while their roots and rhizospheres interact with the

51 below-sediment to drive the productivity of the heterotrophic soil biota [12, 13]. Wetland

52 rhizospheres are essentially oxic-habitats or niches created by the roots' aeration and can

53 markedly affect the diversity of the wetland's heterotrophic biota [14]. Wetlands can influence

54 water and/ or sediment physicochemical properties through different mechanisms including

55 microbial OM mineralization, sedimentation and substrate-adsorption processes $[9,15]$.

Biofilms are ubiquitous and auto-aggregate forms of heterogeneous microbial communities

57 that are attached to each other and can invariably develop on solid surfaces exposed to aquatic

58 environments $[16,17]$. Biofilm communities consisted of bacteria and microalgae which secrete an extracellular polymeric substance matrix (polysaccharides) which facilitates the adhesion of

60 the community to other substrates. The physical nature of biofilm exopolymers has a great

61 adsorptive capacity with a super binding affinity for nutrients [17]. Biofilms can contribute

62 substantially to nutrient cycling, organic matter degradation, and community enrichment due to

63 bacteria mineralization $[9,18,19]$.

Sedimentation is the physical process by which suspended material such as clay, silts and

65 other organic particles found in the water settle by gravity. The resulting sedimentary niche at the settling area could form microbial communities and nutrient-rich ecosystems [20]. Provoost et al.

67 [21] reported that sediment can harbor up to $30 \%$ of the pelagically produced organic matter.

68 Various pollutants in the water body are deposited onto the sediments and through microbial

69 waste degradation processes such as bioremediation undergo biological transformations resulting

70 in increased nutrient cycling, pollution reduction, and bacterial diversity [22-24]. Sediment 
71 microorganisms like heterotrophic marine bacteria are very crucial in nutrients cycling and OM

72 processing [25].

The strength and efficacy of the constructed wetland and biofilm treatments are supported

74 by the consortium of bacterial communities $[9,26]$. Thus, exploring the relationship between

75 biological treatment methods such as constructed wetlands and biofilms on bacterial community

76 and sediment properties is imperative. A couple of studies investigated various effluent treatment

77 systems focusing on microbial community composition and distribution [9, 19, 27]. However,

78 the impacts associated with constructed wetland, biofilm and sedimentation in response to

79 benthic properties, nutrient fluxes, and distribution of bacterial community during

80 bioremediation of aquaculture tail-water remain unclear. In this study, we aimed to (i) evaluate

81 the distribution of microorganisms in constructed wetland, biofilm, and sedimentation (ii)

82 explore the distribution of microbial functional groups among the treatments and (iii) investigate

83 the relationship between nutrient fluxes and microbial functional groups/microbial community.

84 This study will add knowledge on the distributions of sediment microbial community and

85 nutrient fluxes of an aquaculture tail-water treatment system

\section{Materials and Methods}

\section{Study area, Experimental design and Sampling}

88 The experiment was conducted in Ningbo Xiangshan Bay, Zhejiang Province, China, at a

89 land-based aquaculture tail-water treatment system constructed. This system was primarily to

90 restore effluents resulting from an intensive Commercial Vannamei Shrimp (Litopenaeus

91 vannamei) production farm. A comprehensive aquaculture tail-water treatment system composed

92 of subsystems: constructed-wetland, biofilm, and sedimentation was studied [28]. The

93 constructed-wetland subsystem was composed of emergent macrophytes, Spartina anglica, 
94 occupying 400 sq. $m$ of the total system area. The planting densities of S. anglica were $50 \%$ of

95 the total wetland cover. These plants grew rapidly to colonize the wetland and they were not

96 harvested during this study. The biofilm system was deployed with suitable aeration facilities

97 and suspended carriers in the form of fiber threads (adhesive matrix of extracellular polymeric

98 substances) for enhancing the surface area for microorganism attachment. The physical

99 sedimentation consisted of bare sediment surface, overlying aquaculture effluent water, and

100 aeration. This system was involved in filtering and settling large particles of the incoming

101 effluent water from the production center.

102

Sampling started one year after the project launched to let the ecological succession develop.

103

To ensure a representative sampling strategy, data was collected three times consecutively,

104 between April to July. Four different sampling points from each system were identified and sampled. $0.5 \mathrm{~L}$ of the overlying water was collected from each system for water quality analysis.

106 Using a handheld sediment corer four undisturbed sediment cores $(8 \mathrm{~cm}$ height $)$ from each

107 system were gently collected in cylindrical plastic tubes (i.d. $6.4 \mathrm{~cm}$, height $19.4 \mathrm{~cm}$ ). The

108 sediment cores and water samples were immediately brought back to the laboratory for

109 physicochemical analysis and incubation. Water samples were stored at $4^{\circ} \mathrm{C}$, whereas the

110 sediment cores were kept ready for the incubation experiment.

111 The incubation experiment was done as previously described [29]. Water samples for the

112 determination of benthic flux rates for the total ammonia nitrogen (TAN), nitrate $\left(\mathrm{NO}_{3}{ }^{-}-\mathrm{N}\right)$ and

113 nitrite $\left(\mathrm{NO}_{2}{ }^{-}-\mathrm{N}\right)$, and soluble reactive phosphate (SRP) were collected, filtered in $0.45 \mathrm{GF} / \mathrm{F}$ and

114 stored under $-20^{\circ} \mathrm{C}$ until analysis. After the incubation experiment, using a clean stainless steel

115 microspatula, the sediment cores were sliced into three sub-sampling points (surface $0-2 \mathrm{~cm}$,

116 middle $2-4 \mathrm{~cm}$, and bottom 4-8 cm). These subsamples were thoroughly homogenized and 
117 divided into two portions. One potion was freeze-dried for physicochemical contents analysis

118 and the other potion was stored in clean polypropylene tubes at $-20^{\circ} \mathrm{C}$ for the $16 \mathrm{~S}$ rRNA

119 extraction.

120 Analysis of physicochemical contents and nutrient flux rates

121

122

123

124

125

126

127

128

129

130

131

132

133

134

135

136

137

138

139

The physicochemical water parameters (dissolved oxygen, temperature, and salinity) were measured in situ during sampling using a handheld automated YSI 6000 multi-parameter probe (USA). All water samples were analyzed using standard methods [30], where TAN was treated with indophenol blue, $\mathrm{NO}_{2}^{-}-\mathrm{N} / \mathrm{NO}_{3}{ }^{-}-\mathrm{N}$ with the cadmium-copper reduction and the SRP were treated with the ammonium molybdate/ascorbic acid method. All the concentrations of inorganic nutrients were measured using a WESTCO SmartChem discrete analyzer 200 USA. Nutrient flux rates $\left(\mu \mathrm{mol} \mathrm{m} \mathrm{m}^{-2} \mathrm{~h}^{-1}\right)$ and SOC were calculated from slopes of a linear regression concentration against time using the equation previously described [29].

$$
\text { Flux }=\frac{\Delta C \cdot V}{A \cdot t}
$$

Where: Flux is the nutrients or sediment oxygen fluxes $\left(\mathrm{mmol} \mathrm{m}^{-2} \mathrm{~h}^{-1}\right) ; \Delta \mathrm{C}\left(\mathrm{mgL}^{-1}\right)$ is the change in concentration of oxygen/nutrients (prior and after incubation); $\mathrm{V}\left(\mathrm{m}^{3}\right)$ the volume of overlying water; $\mathrm{A}\left(\mathrm{m}^{2}\right)$, is the cross-sectional area of the incubation chamber; $\mathrm{t}(\mathrm{h})$ is the duration of incubation.

The sediment grain size distribution was determined using sieves with different mesh sizes [31]. Briefly, grain-size parameters were conducted mechanically from oven-dried subsamples using standard sieving methods for the sand content $(500-63 \mu \mathrm{m})$ and sedigraph techniques for the silt/clay fraction $(<63 \mu \mathrm{m})$. Particles sizes (clay: $<0.002$, silt: $<0.02$, fine sand: $<0.2$, sand: $<2$ ) were determined. Sediment OM was determined using the loss on ignition method (LOI) [32]. The sediment samples were freeze-dried, pulverized, and pre-weighed before being placed in a muffle furnace at $475^{\circ} \mathrm{C}$ for $4 \mathrm{~h}$. Then the samples were reweighed with the difference equals to 
140 the $\% \mathrm{OM}$ content. TOC (total organic carbon), TON (total organic nitrogen), and $\mathrm{C} / \mathrm{N}$

141 (carbon/nitrogen) ratio were analyzed commercially by using Carbon Elemental Analyzer.

142 Briefly, during pretreatment, $5 \mathrm{~g}$ of the post-freeze-dried wet-sediment were ground using a

143 mortar into powder to pass through a 1-mm mesh sieve. Before analysis, further pretreatment

144 procedures necessary especially for TOC were done to remove the carbon dioxide by adding 1:1

$145 \mathrm{HCl}$ and oven-dried at $80^{\circ} \mathrm{C}$, overnight to a constant weight.

\section{Extraction, amplification and MiSeq sequencing of the benthic bacterial DNA}

The total genomic sediment DNA extraction was performed from $\sim 0.5 \mathrm{~g}$ of homogenized

DNA quality and/or quantity of the samples were measured using a spectrophotometer

157 Then the amplification process followed 30 cycles of $95^{\circ} \mathrm{C}$ denaturation for $30 \mathrm{~s}$, annealing 


\section{Bioinformatics analysis}

The sequencing process of the paired reads was initially joined with FLASH using default settings [33], then, the Raw FASTQ files were processed using Quantitative-Insights-IntoMicrobial-Ecology (QIIME version 1.8.0, [34]. The operational taxonomic units (OTUs) assigned at a $97 \%$ similarity cut-off point in all samples were clustered using USEARCH (version 7.1, http://drive5.com/uparse/). The sequences were quality filtered based on sequence length, quality score, chimera, and primer mismatch thresholds. In a nutshell, homopolymer runs exceeding 6 bp were screened-out by PyroNoise. Sequences with the same barcodes were assigned to the same sample. The phylotypes were performed using the UCLUST algorithm [35]. The most abundant sequences of each phytotype were selected as the clean sequence and were taxonomically assigned (Greengenes database, release 13.8) using PyNAST [36]. Diversity indices (Shannon index, Simpson, Chaol, and observed OTUs) were performed using the phylogenetic tree (QIIME pipeline).

\section{Statistical analyses}

The variations of the different physicochemical variables were analyzed by a one-way or two-way repeated ANOVA. Post Hoc tests were performed to determine the significant groups. The normal distribution and homogeneity of variances among treatments were verified before the ANOVA test. All the data were Hellinger transformed post statistical analyses, and then normalized by using the function decostand/p-p plot in the "vegan" package to improve normality and homoscedasticity. Permutational multivariate analysis of variancePERMANOVA (Bray-Curtis dissimilarity matrices) [37], phyloseq v1.22.3 and Nonmetric Multidimensional Scaling (NMDS) was performed to analyze the microbial community composition among the treatments. One-way analysis of similarity (ANOSIM) was used to 
186

187

188

189

190

191

192

193

194

195

196

197

198

199

200

201

202

203

204

205

206

207

208

verify whether the distribution of different samples visualized in the NMDS plot was significant [38]. Canonical correspondence analysis (CCA) was used to analyze the correlations between bacterial community compositions and environmental variables.

The sediment microbial functional groups were predicted by using the Functional Annotation of Prokaryotic Taxa (FAPROTAX) database. According to Louca et al. [39], the annotated bacterial OTU table from the Silva database was read, and the data was matched with the species information in the database using a python program. The predicted functions were outputted through FAPROTAX (http://www.ehbio.com/ImageGP/). The annotation results were used to describe the microbial functional compositions and abundance of related metabolic pathways involved in ammonification, denitrification, carbohydrate metabolism, aromatics degradation, and nitrogen fixation. The relative abundances of the functional groups were calculated as the cumulative abundance of OTUs assigned to each functional group, which was obtained by standardizing the cumulative abundance of OTUs correlated with at least one function. All statistical analyses were performed with R, (version, 3.6.1) [40] and the results of the statistical tests were considered to be significant at $p \leq 0.05$. The figures were drawn with $R$ and OriginPro 8.0 software. Data deposition: The sequences used in this study have been deposited in the GeneBank of NCBI with the BioProject database ID PRJNA593691 (https://www.ncbi.nlm.nih.gov/sra/PRJNA593691) and SRA accession numbers ranging from SAMN13483434 to SAMN13483469.

\section{Results}

\section{Sediment and water physicochemical contents}

The sediment physicochemical contents are described in Table 1. The results indicate distinct differences in sediment organic and inorganic contents among the systems. The surface 
209

210

211

212

213

214

215

216

217

218

219

220

221

sediments of the constructed-wetland consisted of $79 \%$ medium sand, $17 \%$ very fine sand, and $4 \%$ silt/clay whereases the compositional contents in the biofilm were $68 \%$ medium sand, $25 \%$ very fine sand, and $7 \%$ silt. The sedimentation system was dominated by $84 \%$ (medium sand), $11 \%$ (very fine sand), and 5\% (silt). Cores from the sedimentation system had significantly higher contents of OM, TN, TP, TOC, and C/N ratio at all three depths $(0-2 \mathrm{~cm}, 2-4 \mathrm{~cm}$, and 4-8 $\mathrm{cm}$ ), relative to the others. $\mathrm{C} / \mathrm{N}$ ratio were $8.17 \pm 1.5$ (biofilm), $7.7 \pm 1.6$, (constructed-wetland) and $12.32 \pm 3.1$ (sedimentation) on average. Total OM was much lower in biofilm (depth $0-2 \mathrm{~cm}$ ) compared to constructed-wetland and sedimentation. All sediment organic contents varied differently between the systems however no stable variational trends were observed within different depths of the same treatment (Table 1, $\mathrm{p}>0.05$ ).

Table 1. Mean $( \pm \mathrm{SD})$ values of the sediment organic contents among the treatments (Constructed-wetland, Biofilms, and Sedimentation). OM represents organic matter, TN: Total nitrogen, TP: Total phosphorus, TOC: Total organic carbon and $\mathrm{C} / \mathrm{N}$ : Carbon to nitrogen ratio

\begin{tabular}{ccccccc}
\hline System & Depth (cm) & OM\% & TN\% & TP\% & TOC\% & C/N \\
& & & & & & \\
\hline & Surface & $3.13 \pm 0.14$ & $0.48 \pm 0.05$ & $0.031 \pm 0.061$ & $2.94 \pm 0.06$ & $6.12 \pm 1.31$ \\
& Middle & $3.23 \pm 0.11$ & $0.38 \pm 0.02$ & $0.029 \pm 0.053$ & $3.13 \pm 0.03$ & $8.24 \pm 1.05$ \\
& Bottom & $3.07 \pm 0.08$ & $0.30 \pm 0.12$ & $0.021 \pm 0.006$ & $2.63 \pm 0.04$ & $8.77 \pm 2.09$ \\
BF & Surface & $1.57 \pm 0.05$ & $0.43 \pm 0.03$ & $0.086 \pm 0.04$ & $3.10 \pm 0.06$ & $7.21 \pm 0.81$ \\
& Middle & $2.55 \pm 0.04$ & $0.41 \pm 0.01$ & $0.081 \pm 0.03$ & $3.07 \pm 0.02$ & $7.49 \pm 3.32$ \\
& Bottom & $3.47 \pm 1.02$ & $0.22 \pm 0.01$ & $0.952 \pm 0.02$ & $2.16 \pm 0.08$ & $9.82 \pm 3.74$ \\
& Surface & $4.79 \pm 0.26$ & $0.16 \pm 0.01$ & $0.263 \pm 0.01$ & $2.31 \pm 0.06$ & $14.43 \pm 5.64$ \\
& Middle & $4.12 \pm 0.24$ & $0.21 \pm 0.01$ & $0.289 \pm 0.041$ & $2.33 \pm 0.25$ & $11.09 \pm 4.81$ \\
& & & & & & \\
& Bottom & $3.98 \pm 0.31$ & $0.26 \pm 0.12$ & $0.204 \pm 0.025$ & $2.98 \pm 0.22$ & $11.46 \pm 6.06$
\end{tabular}




\section{Nutrients flux rates among the treatments}

All dissolved inorganic nutrient flux rates showed an efflux trend among the treatments. The mean release rates of TAN, $\mathrm{NO}_{3}{ }^{-}-\mathrm{N}, \mathrm{NO}_{2}{ }^{-}-\mathrm{N}$, and SRP fluxes between biofilm, constructedwetland, and sedimentation cores were significantly different (2-way ANOVA, $\mathrm{p}<0.05) . \mathrm{NO}_{2}^{-}-\mathrm{N}$ and TAN accounted for more than $87.51 \%$ (constructed-wetland) and $71.14 \%$ (biofilm) net flux rate relative to $37.43 \%$ (sedimentation) (Fig 1). The $\mathrm{NO}_{3}{ }^{-}-\mathrm{N}$ flux rates were $396.15 \pm 61.09 \mu \mathrm{mol}$

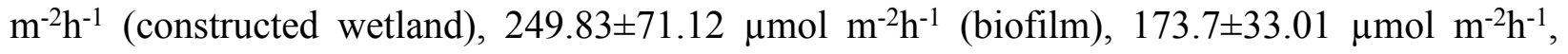
(sedimentation) (Fig 1B). The constructed wetland had the highest exchange rate of $\mathrm{NO}_{3}^{-}-\mathrm{N}$, and $\mathrm{NO}_{2}^{-}-\mathrm{N}$ relative to other systems (biofilm and sedimentation). The SRP had the highest mean flux rate in biofilm. The release rate of TAN into the overlying water (constructed-wetland) was approximately twice higher in both biofilm and sedimentation, indicating sedimentary remineralization of ammonia and nitrate. SOC were $4.91 \pm 0.75 \mathrm{mmol} \mathrm{m}^{-2} \mathrm{~h}^{-1}$ (biofilm), $3.82 \pm 0.37$ mmol m $\mathrm{m}^{-2} \mathrm{~h}^{-1}$ (constructed wetland), $1.89 \pm 0.31 \mathrm{mmol} \mathrm{m}^{-2} \mathrm{~h}^{-1}$ (sedimentation) (Fig 1A). Oxygen level in sedimentation subsystem was the lowest followed by constructed wetland and finally biofilm. Generally, the mean release rates of all nutrient groups including soc followed the order: biofilm $>$ constructed wetland $>$ sedimentation.

\section{[Fig 1]}

\section{Microbial community composition and structure}

The bacterial community compositions varied among depths and between the treatment systems (Fig 2). A total of 519, 692, and 837 OTUs were identified for sedimentation, constructed-wetland, and biofilm treatments respectively. Jointly the OTUs represent 54 phyla, 85 classes, 152 families, and 471 genera among all treatments. The relative content of the microbial community ( $>0.3 \%$ relative abundance) at phylum, class, and family level is illustrated 
246 (Fig 2A-C). At the phylum level, Proteobacteria were the most dominant community in all three 247 systems accounting for $32.17 \pm 7.51 \%$, followed by Bacteroidetes $(29.32 \pm 7.04 \%$ ), Chloroflexi 248 (20.65 $\pm 6.21 \%)$, Actinobacteria (19.44 $\pm 5.92 \%)$, Firmicutes (13.92 $\pm 4.09 \%)$, Acinetobacter $249(11.85 \pm 3.71 \%)$ and Planctomycetes $(8.83 \pm 2.54 \%)$ (Fig. 2A). The phylum Firmicutes and 250 Proteobacteria were most dominant in constructed wetland and biofilm, while the sedimentation 251 community was mainly dispersed by Firmicutes, Proteobacteria, and Bacteroidetes. Gamma-, 252 Delta-, and Alpha-proteobacteria were dominant classes in all systems, followed by 253 Anaerolineae, Actinobacteria, Cytophagia, and Flavobacteriia (Fig 2B). Further, at the family 254 level, several predominantly expressed bacterial taxa ((Clostridiaceae and 255 Acidaminobacteraceae, (Order-Clostridiales), Rhodobacteraceae (Order-Rhodobacterales) 256 Chloroflexi, Anaerolineaceae, [Thermodesulfovibrionaceae] (order-Nitrospirales) were 257 predominant in all three treatments (Fig 2C). The family Flavobacteriaceae was highly 258 distributed in biofilm (15 to 65-fold) relative to constructed-wetland (9-31-fold) and sedimentation (7-17-fold). Other families were Nitrospiraceae and Planctomycetaceae with a 20-50-fold higher (biofilm) relative to constructed-wetland and sedimentation (jointly 6-12-fold).

261 The distribution of the most dominant bacterial community (at the genera level) among the 262 treatments is represented by heatmap (Fig 3). The heatmap includes the top thirty genera, which 263 represent $94.2-97.5 \%$ of all $16 \mathrm{~S}$ rRNA bacterial genes reads. The Disulvococcus, 264 Novosphingomium, Fusibacteria, Kordia, Clostridium, and Lysobacter were the genera highly 265 distributed among the treatments (Fig 3; 0-4 $\mathrm{cm}$ depth). Vertically, the proportions of 266 Proteobacteria, Acidobacteria, and Bacteroidetes were high in surface sediments, whereas 267 Chloroflexi and Firmicutes tended to be enriched in deep layers. 


\section{[Fig 2]}

\section{Diversity of bacterial community among the systems}

The bacterial community differed significantly among the treatments (ANOSIM, $\mathrm{p}=0.031$ ).

272 The microbial community richness estimate (Chao1) ranged from 7321 to 9531 sequences

273 (biofilm), 4637 to 9017 (constructed-wetland), 6214 to 8973 (sedimentation). Biofilm had

274 significantly Chaol values $(\mathrm{p}<0.05)$ and constructed-wetland had the highest bacterial diversity

275 (Shannon index values). Bacterial richness estimates were highest and most diverse at the surface

276 sediments $(0-2 \mathrm{~cm})$ and dropped with a depth increase (Fig 3). The Shannon index ranged from

279 (surface), 3.5 (middle), 2.53 (bottom). The diversity trend order was constructeddifferences in community composition grouping patterns between the systems, and between depths (Fig 4). The samples were grouped separately within depths and between treatments. The microbial community in constructed-wetland treatment samples was more clearly separated suggesting the highest species dissimilarity compared to other treatments. PERMANOVA groups was significantly different (Table 2: $\mathrm{p}<0.05$ ).

Table 2. 16S rRNA sediment microbial community distributions, structure, and composition 


\begin{tabular}{lccccc}
\hline & Sums of Sqs & Means Sqs & F. Model & $\mathbf{R}^{2}$ & P \\
\hline Groups & 3.0131 & 1.73516 & 7.7641 & 0.29737 & $0.000^{*}$ \\
Depth & 0.9362 & 0.58454 & 4.5153 & 0.34574 & $0.003^{*}$ \\
Groups*Depth & 0.1795 & 0.30134 & 1.9438 & 0.03952 & $0.042^{*}$ \\
\hline
\end{tabular}

294

295

296

297

298

299

300

301

302

303

304

305

306

307

308

309

310

311

312

\section{[Fig 3]}

[Fig 4]

\section{Microbial community and environmental variables}

To explore the relationship between the sediment-microbial community and environmental factors, a correlation analysis was performed based on CCA. The analysis showed significant correlations between microbial community composition (genus level) and the environmental factors (Mantel test, $\mathrm{p}<0.05$ ). The CCA showed the two components of the graph jointly explained $78.89 \%$ (axis 1: $41.37 \%$ and axis 2: $29.52 \%$ ) of the total sediment microbial community variance, implying that physicochemical factors and bacterial community composition/structure had a substantive influence over the other. Generally, nine environmental variables were significantly associated with the bacterial community among the treatments (Fig 5). The weakest correlation was observed between $\mathrm{SRP}$ and $\mathrm{NO}_{2}^{-}-\mathrm{N}$ and the communities (sedimentation). A significant correlation between Desulphobacterales, Nitrospira, and Clostridia taxa and the variables TN, TOC, and TP were evident. Significant correlations between Nitrospira and TOC, TN, and SRP (biofilm) and TAN in the constructed-wetland samples were observed. Furthermore, significant correlations between Desulfomicrobium, Cytophagales, and Planctomyces and $\mathrm{NO}_{2}^{-}-\mathrm{N}$, and $\mathrm{TP}$ in the sedimentation samples were found. 

5).

\section{Sediment microbial functional groups distributions}

Using FAPROTAX the analysis revealed a comparative number of various specific

327 included aerobic-chemoheterotrophy, sulfate_respiration, nitrate_ammonification, and sedimentation samples.

\section{[Fig 6]}

\section{Discussion}

Biofilm, constructed wetland, and sedimentation are potential treatments for improving wastewater and sediment quality [9, 8]. This treatment can improve the ecosystem processes

335 including sediment microbial community activities, distribution, structure, abundance, and 
337 to improve and optimize the bioremediation process [8, 41, 42]. This study indicates that a

338 couple of ecological activities including microorganism distribution patterns, nutrient dynamics,

339 and contents of the OM were significantly influenced by the treatments

340 Microbial community composition and distribution

341 The sedimentary bacterial community compositions and structure among the treatments

342 were differently distributed (Figs 3, 4; Table 2). Biofilm and constructed wetland treatments

343 supported more abundant and distinct microbial communities especially at the surface layers (Fig

344 2). Particularly, phyla such as Proteobacteria and Acidobacteria were most abundantly

345 distributed across all samples, with the highest relative abundance been recorded in biofilm

346 samples relative to constructed-wetland and sedimentation suggesting an elevated mineralization

347 hence nutrient fluxes (Fig 1). This suggests that the treatments probably created varying

348 ecological conditions that accelerate microbial activities and multiplication. The Proteobacteria,

349 Bacteroidetes, Acidobacteria, Deltaproteobacteria, Clostridia, Firmicutes

350 Gammaproteobacteria, and Bacilli were among the most dominant phyla with approximately

$351 \quad 37 \%$ and $43 \%$ bacterial composition in constructed-wetland and biofilm respectively compared

352 sedimentation (19\%) (Fig 4). Some studies suggest that soil microbial distribution can be

353 regulated by the different vegetation types $[43,44]$. In this study, microbial diversity was highly

354 distributed especially within the constructed-wetland subsystem (Figs. 2A-C, 3). Bodelier, [45]

355 and Lukwambe et al. [9] wetland rhizospheres are oxic-habitats created by the roots' aeration

356 and can markedly affect the diversity of the wetland's heterotrophic biota and activate nutrient

357 fluxes.

There is a substantial interaction among the constructed wetland plants, microorganisms,

359 and contaminants supported by their complex rhizosphere system [46]. Besides, the plants roots 
360 forming the constructed-wetland harbor/store useful nitrifying-denitrifying bacteria [47]. This is

361 evident especially with the rhizosphere of emergent aquatic plants, where the plant roots provide

362 a favorable habitat and exudate the growth of various microbes responsible for sediment

363 reworking including sediment nitrogen content transformation [48, 49]. A profound number of

364 Proteobacteria, Chloroflexi, and Acidobacteria, were observed within the biofilm and

365 constructed wetland, this may suggest the presence of elevated mineralization activities which

366 affect the succession and stability of the bacterial community [50, 51, 52]. Also, a biofilm

367 environment can potentially improve bacterial communities distributions [53]. Based on this

368 observation, we can deduce that both biofilms and constructed wetlands favored more bacterial

369 community related to organic wastes degradation relative to other sedimentation systems.

370 Its known remediation measures by using constructed-wetland, biofilm, and sedimentation

371 are known to influence the aquatic ecosystem biodiversity due to improved sediment conditions

372 [29]. The sedimentary ecological niches created by each system differently affect the biotic and

373 abiotic characteristics, thereby resulting in the change of the aquatic microbial diversity and

374 functional diversity [54].

\section{Biogeochemical fluxes and functional microbial community}

376 In the current study, constructed-wetland showed higher $\mathrm{SRP}, \mathrm{NO}_{2}^{-}-\mathrm{N}, \mathrm{NO}_{3}^{-}-\mathrm{N}$, and TAN

377 flux rates relative to other treatments (Fig 1). This release pattern is ascribed to promoted 378 physicochemical-microbial mediated activities such as mineralization, nitrification379 denitrification, and redox reaction [8, 19]. Literatures show that the root system of the 380 constructed-wetland plants has rhizomes that aerate the sediment potentially resulting in 381 increased dissolved oxygen which promotes microbial assemblages and nitrification382 denitrification activities $[9,55,56]$. In this study, we found several bacterial taxa associated with 
383

384

ammonium oxidizing bacterial (AOB, e.g., Nitrospira) and nitrite-oxidizing bacteria (NOB, Nitrospina, Nitrosomonas) and sulfate-reducing bacteria (SRB, Desulfatibacillum and Desulfobacterium) which contribute to effluent degradation and material transformation [26, 56].

These species were enriched in both constructed wetland and biofilm indicating that the elevated nutrient fluxes were probably due to enhanced bacterial activities such as organic matter mineralization. On the other hand, putatively performing dissimilatory nitrate reduction to ammonia taxa were about 2.5- to 3-fold more in biofilm and constructed-wetland suggesting an increased mineralization activity including nitrification. Normally nitrification process is facilitated by both $\mathrm{AOB}$ and $\mathrm{NOB}$ bacterial [57]. Under the presence of oxygen microbial nitrogen transformation is supported. Vila-Costa et al. [58] reported that macrophyte species with high root oxygen release capacity may enhance the diversity and activity of ammonia oxidizers leading to increased nitrogen content transformation.

Lower TAN fluxes were observed in the biofilm treatment system suggesting increased ammonia utilization by nitrifying bacteria such as Nitrosomonas and Nitrobacter. These group of bacterial are reported to reduce excess nitrogenous content in the sediment [19]. In our study, several bacterial functional groups related to biogeochemical nutrient metabolism, cycling, and degradation were discovered (Fig 6). The expression of chemoheterotrophy, aerobicchemoheterotrophy, and denitrification microbial functional groups was significantly higher in the constructed wetland than biofilm and sedimentation. This implied that constructed-wetland best enhanced the activities related to effluent degradation that led to increased nutrient transformation and fluxes. This as well suggests that the genes associated with different biogeochemical functions were favored and enhanced. Sediment nitrogen fixation, nitrification, denitrification, ammonification, and other major nitrogen transformation processes are mediated 
by soil bacteria $[56,59]$. The sedimentary nitrogen cycle can be improved by biological nitrification and denitrification pathways leading to healthy environmental ecosystems. For example, we observed an increase in the absolute content of functional group related Acinetobacter (Moraxellaceae), which is responsible for detoxification of different pollutants, such as degradation of aromatic compounds [60]. The increased SRP flux rate from the sediment into the water (biofilm, Fig. 1B) indicates organic matter transformation could have been promoted by the bacterial community. $\mathrm{Ki}$ et al. [56] indicated that organic wastes can be decomposed into soluble reactive phosphate by the SRB bacteria, such as Desulfobacterium, Desulfatibacillum, Desulfomicrobium, and Desulfosalsimonas, which were most evident in both biofilm and constructed-wetland.

\section{Bacterial community and sediment organic contents}

The content of TON, TOC, TP, and TOM varied significantly among the treatments (Table 1). The observed distribution trend was likely due to improved bacterial community activities associated with mineralization, such as nitrification-denitrification. Sediment nitrogen fixation, nitrification, denitrification, ammonification, and other major nitrogen transformation processes are mainly mediated by soil bacteria [59]. The expression of Dechloromonas, Steroidobacter, and Novosphingobium among the treatments are likely to support the denitrification process and strengthen the physicochemical-microbial interactions. For instance, Dechloromonas has been described as denitrifers that produce nitrogen gas as a reduced nitrogen product [61]. Fabian et al. [62] stated that denitrification can also be fueled by the presence of Steroidobacter in the sediments. Generally, the lower TN and OM in biofilm and constructed wetland over the sedimentation is probably due to the TAN transformation through microbial oxidation to $\mathrm{NO}_{3}^{-}-\mathrm{N}$ and $\mathrm{NO}_{3}{ }^{-}-\mathrm{N}$. The majority of nitrogen content reduction in wetlands is believed to result from the 
429 microbial coupled nitrification-denitrification interactions and uptake by the wetland plants [63].

430 The 16S rRNA sequencing result showed that taxa such as Firmicutes and Nitrospinae were

431 differentially enriched among the treatments a phenomenon that may have attributed to the

432 reduced level of the organic contents.

433 Additionally, CCA indicated strong relationships between the bacterial communities and

434 physicochemical factors (Fig 5). Among the treatments, nine environmental variables (TAN,

$435 \mathrm{NO}_{2}^{-}-\mathrm{N}, \mathrm{NO}_{3}^{-}-\mathrm{N}, \mathrm{SRP}, \mathrm{TN}, \mathrm{TP}, \mathrm{TOC}, \mathrm{OM}$ and, SOC) correlated more closely with microbial

436 community groups. The correlations between bacterial communities and nutrient fluxes and

437 organics were moderately high (ordination axis $1=58.1 \%$, axis $2=42.7 \%$ of the total variation).

438 The constructed-wetland and biofilm had more affiliated taxa linked with physicochemical

439 variables relative to sedimentation indicating a greater association between the functional genera

440 among the two treatments. This result is similar to $\mathrm{Wu}$ et al. [64], Lukwambe et al. [29] and Ki

441 et al. [56] who reported a substantial correlation among the bacteria and nitrogen transformation.

442 In similar patterns, CCA results revealed that TAN, TP, TOC, and TN contents were factors that

443 strongly correlated with Desulfomicrobium (surface sediment) and Chloroflex (deeper sediment,

444 biofilm) while SOC, TP, and SRP mostly correlated with Ferrimonas, Burkholderia,

445 Dechloromonas, and Desulfomicrobium, especially in constructed-wetland. This can be

446 supported by a previous study [56, 65] which indicated Desulfomicrobiuim and Methylobacter

447 had strong association with TAN resulting in reduced organic contents.

\section{Conclusions}

449 This study investigates the distributions of the bacterial community, nutrient-fluxes, and

450 organic matter contents in a comprehensive aquaculture tail-water treatment system. The study

451 showed that the treatments differently improved the sediment bacterial dynamics (community 
452 structure, diversity, and composition), elevated nutrient dynamics and fluxes, and reduced

453 organic matter contents. Microbial groups associated with AOB, NOB, SRB were enriched in the

454 constructed wetland and biofilm but so within the $0-4 \mathrm{~cm}$ sediment depth. The

455 chemoheterotrophy, aerobic-chemoheterotrophy, denitrification, and nitrification were the most

456 dominant functional groups of all treatments but especially in the constructed wetland. The TAN,

$457 \mathrm{NO}_{2}^{-}-\mathrm{N}$, and $\mathrm{NO}_{3}^{-}-\mathrm{N}$ nutrient flux rates across the sediment-water interface were higher in

458 constructed-wetland than in biofilm and sedimentation subsystems. The constructed-wetland and

459 biofilm had lower organic effluents and better sediment conditions relative to sedimentation. Our

460 study suggests that bacterial diversity and structure were highly improved especially under

461 constructed-wetland. Whereas biofilm best promoted the bacterial community composition

462 relative to other treatments.

463 Acknowledgments

464 This study was supported by National Key R \& D Program of China (2020YFD0900201), the

465 Zhejiang Public Welfare Technology Research Program of China (ZPWTP) (LGN18C190008)

466 and the K.C. Wong Magna Fund in Ningbo University

467

\section{References}

1. Kalantzi I, Karakassis I. Benthic impacts of fish farming: meta-analysis of community and geochemical data. Mar. Pollut. Bull. 2006; 52:484-493. 1144. human and animal health and for the environment. Environ Microbiol. 2006; 8:1137- 
Wassie M. The Role of Microorganisms in Bioremediation- A Review. OJEB. 2017; 2(1): 038-046.

478

479

480

481

482

483

484

485

486

487

488

489

490

491

492

493

494

495

496

497

4. Dean RJ, Shimmield TM, Black KD. Copper, zinc and cadmium in marine cage fish farm sediments: an extensive survey. Environ Pollut. 2007; 145:84-95.

5. Basaran AK, Aksu M, Egemen O. Impacts of the fish farms on the water column nutrient concentrations and accumulation of heavy metals in the sediments in the eastern Aegean Sea (Turkey). Environ Monit Assess. 2010; 162:439-51.

6. Martinez-Porchaz M, Martinez-Cordova LR. World aquaculture: Environmental impacts and troubleshooting alternatives. Sci. World J. 2012; 389623

7. Brito LO., Cardoso Junior L, de O, Lavander HD, Abreu JL, de Severi W, Gálvez AO. Bioremediation of shrimp biofloc wastewater using clam, seaweed, and fish, Chem Ecol . $2018 ; 1-13$

8. Nicholaus R, Lukwambe B, Lai H, Yang W, Zheng Z Nutrients cycling in ecological aquaculture wastewater treatment systems: vertical distribution of benthic phosphorus fractions due to bioturbation activity by Tegillarca granosa. Aquaculture Environ Interact. 2019a; 11: 469-480.

9. Lukwambe B, Zhao L, Nicholaus R, Yang W, Zhu J, Zheng Z. Bacterioplankton community in response to biological filters (clam, biofilm, and macrophytes) in an integrated aquaculture wastewater bioremediation system. Environ. Pollut. 2019; 254 113035.

10. Kivaisi AK. The potential for constructed wetlands for wastewater treatment and reuse in developing countries: a review, Ecol Eng. 2001; 16(4): 545-560. 

Halophyte filter beds for treatment of saline wastewater from aquaculture. Water Res. 2012; 46:5102-5114.

501

502

503

504

505

506

507

508

509

510

12. Neori A, Agami M. The Functioning of Rhizosphere Biota in Wetlands- a Review. Wetlands. 2016; 37(4): 615-633.

13. Bonkowski M, Villenave C, Griffiths B. Rhizosphere fauna: the functional and structural diversity of intimate interactions of soil fauna with plant roots. Plant Soil. 2009; 321: 213-233.

14. Bodelier PLE. Interactions between oxygen-releasing roots and microbial processes in flooded soils and sediments. In: de Kroon H, Visser EJW (eds) Root ecology. Ecological studies Vol. 168. Springer-Verlag Berlin Heidelberg, Germany. 2003; 331-362

15. Kadlec RH, Knight RL. Treatment Wetlands, Lewis publisher, New York, NY, USA. 1996

16. Rao TS, Rani PG, Venugopalan VP, Nair KVK Biofilm formation in a freshwater environment under photic and aphotic conditions. Biofouling. 1997; 11:265-282.

17. Sanz-Lázaro C, Navarrete-Mier F, Marín A. Biofilm responses to marine fish farm wastes. Environ Pollut. 2011; 159(3), 825-832.

18. Baldwin DS, Mitchell AM, Rees GN, Watson GO, Williams JL. Nitrogen processing by biofilms along a lowland river continuum. River Res Appl. 2006; 22: 319-326

19. Nicholaus R, Lukwambe B, Zhao L, Yang W, Zhu J, Zheng Z Bioturbation of blood clam Tegillarca granosa on benthic nutrient fluxes and microbial community in an aquaculture wastewater treatment system. Int. Biodeterior. Biodegradation. 2019b; 142:73-82. 
20. Freel KC, Edlund A, Jensen PR Microdiversity and evidence for high dispersal rates in the marine actinomycete Salinispora pacifica. Environ. Microbiol. 2012; 14:480-93.

21. Provoost P, Braeckman U, Van Gansbeke D, Moodley L, Soetaert K, Middelburg JJ, Jan Vanaverbeke J. Modelling benthic oxygen consumption and benthic-pelagic coupling at a shallow station in the southern North Sea. Estuar. Coast. Shelf Sci. 2013: 120: 1-11.

22. Abatenh E, Gizaw B, Tsegaye Z, Wassie M. The Role of Microorganisms in Bioremediation- A Review. OJEB. 2017; 2(1): 038-046.

23. Nicholaus R, Lukwambe B, Yang W, et al. In situ Assemblies of Bacteria and Nutrient Dynamics in Response to an Ecosystem Engineer, Marine Clam Scapharca subcrenata, in the Sediment of an Aquaculture Bioremediation System. J Ocean Univ. Chin. 2020a; 19: $1447-1460$

24. Nicholaus R, Lukwambe B, Mwakalapa EB, Yang W, Zhu J, Zheng Z. Impacts of bioturbation by Venus clam Cyclina sinensis (Gmelin, 1791) on benthic metabolism and sediment nutrient dynamics in a shrimp-clam polyculture pond. Indian Journal of Fisheries Science. 2020b. 167(3):29-38

25. Vega Thurber R. Willner-Hall D, Rodriguez-Mueller B, Desnues C, Edwards RA, Angly F, Dinsedimentionale E, Kelly Forest Rohwer L. Metagenomic analysis of stressed coral holobionts. Environ Microbiol. 2009; 11(8):2148-63.

26. Soares-Castro P, Yadav TC, Viggor S, Kivisaar M, Kapley A, Santos PM Seasonal bacterial community dynamics in a crude oil refinery wastewater treatment plant. Appl. Microbiol. Biotechnol. 2019; 103:9131-9141. 
27. Akyon B, Stachler E, Wei N, Bibby K. Microbial Mats as a Biological Treatment Approach for Saline Wastewaters: The Case of Produced Water from Hydraulic Fracturing. Environ Sci Technol. 2015; 49(10): 6172-6180.

28. Lukwambe B, Yang W, Zheng Y, Nicholaus R, Zhu J, Zheng Z. Bioturbation by the razor clam (Sinonovacula constricta) on the microbial community and enzymatic activities in the sediment of an ecological aquaculture wastewater treatment system. Sci. Total Environ. 2018; 643: 1098-1107

29. Nicholaus R, Zheng ZM. The effects of bioturbation by the Venus clam Cyclina sinensis on the fluxes of nutrients across the sediment-water interface in aquaculture ponds. Aquac Int.2014; 22(2):913-924.

30. APHA. Standard methods for the examination of water and wastewater, 22nd edition edited by Rice EW, Baird, RB, Eaton, AD and Clesceri LS, American Public Health Association (APHA), American Water Works Association (AWWA) and Water Environment Federation (WEF), Washington, DC, USA; 2012

31. Giles H, Pilditch CA, Nodder SD, Zeldis JR, Currie K. Benthic oxygen fluxes and sediment properties on the northeastern New Zealand continental shelf. Cont. Shelf Res. 2007; 27(18): 2373-2388.

32. Heiri O, Lotter AF, Lemcke G Loss on ignition as a method for estimating organic and carbonate content in sediments: reproducibility and comparability of results. J. Paleolimnol. 2001; 25: 101-110.

33. Magoč T, Salzberg SL FLASH: fast length adjustment of short reads to improve genome assemblies. Bioinformatics. 2011; 27:2957-2963. 
34. Caporaso JG, Bittinger K, Bushman FD, DeSantis TZ, Andersen GL, Knight R. PyNAST: a flexible tool for aligning sequences to a template alignment. Bioinformatics. 2010: 26: $266-267$.

35. Edgar RC. UPARSE: highly accurate otu sequences from microbial amplicon reads. Nat Methods. 2013; 10: 996-998.

36. DeSantis TZ, Hugenholtz P, Keller K, Brodie EL, Larsen N, Piceno YM, Phan R, Andersen GL. NAST: a multiple sequence alignment server for comparative analysis of 16S rRNA genes. Nucleic Acids Res. 2006; 34: 394-399

37. Anderson MJ. A new method for non-parametric multivariate analysis of variance. Austral Ecol. 2001; 26:32-46.

38. Legendre P, Legendre L Numerical ecology: second English edition. Dev. Environ. Model. 1998; 20

39. Louca S, Jacques SMS, Pires APF, Leal JS, González AL, Doebeli M, Farjalla VF. Functional structure of the bromeliad tank microbiome is strongly shaped by local geochemical conditions. Environ Microbiol. 2017; 19(8): 3132-3151

40. R Core Team. R: A language and environment for statistical computing. R Foundation for Statistical Computing, Vienna, Austria. URL https://www.R-project.org/.2019

41. Shen H, Jiang G, Wan X, Li H, Qiao Y, Thrush S, He P. Response of the microbial community to bioturbation by benthic macrofauna on intertidal flats. J Exp Mar Biol Ecol. $2017 ; 488,44-51$.

42. Bharagava RN, Purchase D, Saxena G, and Mulla SI. Applications of Metagenomics in Microbial Bioremediation of Pollutants. Microbial Diversity in the Genomic Era. 2019; $459-477$. 
43. Deng J, Yin Y, Zhu W, Zhou Y. Variations in Soil Bacterial Community Diversity and Structures Among Different Revegetation Types in the Baishilazi Nature Reserve. Front. Microbiol. 2018; 9: 2874

44. Deng J, Zhang Y, Yin Y, Zhu X, Zhu W, Zhou Y. Comparison of soil bacterial community and functional characteristics following afforestation in the semi-arid areas. PeerJ. 2019; 7: e7141

45. Bodelier PLE. Interactions between oxygen-releasing roots and microbial processes in flooded soils and sediments. In: de Kroon H, Visser EJW (eds) Root ecology. Ecological studies Vol. 168. Springer-Verlag Berlin Heidelberg, Germany. 2003; 331-362

46. Carvalho PN, Araujo JL, Mucha AP, Basto MC, Almeida CM. Potential of constructed wetlands microcosms for the removal of veterinary pharmaceuticals from livestock wastewater. Bioresour Technol. 2013; 134: 412-416.

47. Chen ZJ, Shao Y, Li YJ, Lin LA, Chen Y, Tian W, Li BL, Li YY. Rhizosphere Bacterial Community Structure and Predicted Functional Analysis in the Water-Level Fluctuation Zone of the Danjiangkou Reservoir in China During the Dry Period.Int J Environ Res Public Health. 2020; 17(4): 1266.

48. Zhang XY, Wang ZZ, Liu XY, Hu X. Degradation of diesel pollutants in HuangpuYangtze River estuary wetland using plant-microbe systems. Int Biodeterior Biodegradation. 2013; 76: 71e75.

49. Zou J, Liu X, He C, Zhang X, Zhong C, Wang C, Wei J. Effect of Scripus triqueter of its rhizosphere and root exudates on microbial community structure of simulated dieselspiked wetland. Int Biodeterior Biodegradation 2013; 82: 110-116. 
50. Thomas JC, Cable E, Dabkowski RT, Gargala S, McCall D, Pangrazzi G, Pierson A, Ripper M, Russell DK, Rugh CL. Native Michigan plants stimulate soil microbial species changes and PAH remediation at a legacy steel mill. Int J Phytoremediation. 2012; 15: 523

51. Nguyen NL, Kim YJ, Hoang VA, Subramaniyam S, Kang JP, Kang CH, Yang DC Bacterial Diversity and Community Structure in Korean Ginseng Field Soil Are Shifted by Cultivation Time. PLOS One. 2016; 11(5), e0155055.

52. Zhang B, Li Y, Xiang SZ, Yan Y, Yang, R, Lin MP, Wang XM, Xue YL, Guan XY. Sediment Microbial Communities and Their Potential Role as Environmental Pollution Indicators in Xuande Atoll, South China Sea. Front Microbiol. 2020; 11:1011.

53. Song W, Qi R, Zhao L, Xue N, Wang L, Yang Y. Bacterial community rather than metals shaping metal resistance genes in water, sediment and biofilm in lakes from arid northwestern China. Environ Pollut. 2019. 254: 113041.

54. Zhang S, Pang S, Wang P, Wang C, Guo C, Addo FG, Li Y Responses of bacterial community structure and denitrifying bacteria in biofilm to submerged macrophytes and nitrate. Sci. Rep. 2016; 6(1): 36178

55. Faulwetter JL, Gagnon V, Sundberg C, Chazarenc F, Burr, MD, Brisson, J, Camper AK, Stein OR. Microbial processes influencing performance of treatment wetlands: a review. Ecol. Eng. 2009; 35: 987-1004.

56. Ki BM, Huh IA, Choi JH, Cho KS Relationship of nutrient dynamics and bacterial community structure at the water-sediment interface using a benthic chamber experiment. J. Environ. Sci. Health A. 2018; 53(5): 482-491. 
57. Mosier AC, Francis CA. Relative abundance and diversity of ammonia-oxidizing archaea and bacteria in the San Francisco Bay estuary. Environ. Microbiol. 2008; 10:3002-3016.

58. Vila-Costa M, Pulido C, Chappuis E, Calviño A, Casamayor EO, Gacia E. Macrophyte landscape modulates lake ecosystem-level nitrogen losses through tightly coupled plantmicrobe interactions. Limnol Oceanogr. 2015; 61(1): 78-88

59. Yoon S, Cruz-García C, Sanford R, Ritalahti KM, Löffler FE Denitrification versus respiratory ammonification: environmental controls of two competing dissimilatory NO3(-)/NO2(-) reduction pathways in Shewanella loihica strain PV-4. The ISME Journal. 2015; 9(5):1093-1104.

60. Felföldi T, Székely AJ, Gorál R, Barkacs K, Scheirich G, András J, Márialigeti K. Polyphasic bacterial community analysis of an aerobic activated sludge removing phenols and thiocyanate from coke plant effluent. Bioresour. Technol. 2010; 101: 3406-3414.

61. Weber KA, Urrutia MM, Churchill PF, Kukkadapu RK, Roden EE. Anaerobic redox cycling of iron by freshwater sediment microorganisms. Environ Microbiol. 2006; 8:100113.

62. Fabian M, Marrale D, Misic C. Bacteria and organic matter dynamics during a bioremediation treatment of organic-rich harbor sediments. Mar Pollut Bull. 2003; 46: 1164-1173.

63. Haddad HR, Maine MA, Bonetto CA. Macrophyte growth in a pilot-scale constructed wetland for industrial wastewater treatment. Chemosphere. 2006; 63(10): 1744-1753.

64. Wu Q, Zhang R, Huang S, Zhang H. Effects of bacteria on nitrogen and phosphorus release from river sediment. J Environ Sci. 2008; 20: 404-412. 
65. Sinkko H, Lukkari K, Sihvonen LM, Sivonen K, Leivuori M, Rantanen M, Paulin L, Lyra C. Bacteria contribute to sediment nutrient release and reflect progressed eutrophication-driven hypoxia in an organic-rich continental sea. PLOS One. 2013; 8: e67061.

\section{Figure Legends}

Fig 1 Benthic inorganic nutrient flux rates. (A) Sediment oxygen consumption- SOC and (B) (Total ammonia nitrogen- TAN, nitrate, nitrite and soluble reactive phosphate- SRP) estimated during laboratory incubations (mean $\pm \mathrm{SD}, \mathrm{n}=3)$ in each treatment system

Fig 2 The relative abundance of the vertical sediment microbial community composition and diversity among the treatment systems (Biofilm, Constructed-wetland, Sedimentation) at the phylum (A), class (B) and family (C) levels revealed by 16S rRNA genes sequencing. Taxa making up less than $0.03 \%$ of total composition in all libraries were classified as 'others'

Fig 3 Alpha diversity estimates of each treatment at different sampling depths obtained by 16S rRNA genes high-throughput sequencing. (A) Number of OTUs, (B) Chao1 richness estimate index, (C) Shannon index and (D) Simpson

Fig 4 Non-metric multidimensional scaling plot based on the Bray-Curtis dissimilarity showing the relationship between the samples in each treatment. Shapes in triangle, circles, and squares represent biofilm, constructed-wetland, and sedimentation treatments respectively. Colors in brown, blue and green represent samples at the surface, middle and bottom sediment depth in each system respectively

Fig 5 Canonical Correspondence Analysis ordination plot showing the relationships between bacterial community and physicochemical variables in the three treatments of the aquaculture 
676 tail-water treatment system. Samples collected from the surface, middle, and bottom of each

677 system are designated with blue, orange, and green triangles, respectively. The abbreviations

678 indicate sediment oxygen consumption (SOC), total- organic matter (TOM), organic nitrogen

679 (TON), ammonia nitrogen (TAN), phosphate (TP), nitrate $\left(\mathrm{NO}_{3}^{-}-\mathrm{N}\right)$, nitrite $\left(\mathrm{NO}_{2}^{-}-\mathrm{N}\right)$ and

680 sediment reactive phosphate (SRP)

681 Fig 6 Bar plot of the relative abundance distributions of the predicted predominant functional

682 groups among the treatments as annotated by the FAPROTAX database. 


\section{Figures}

2
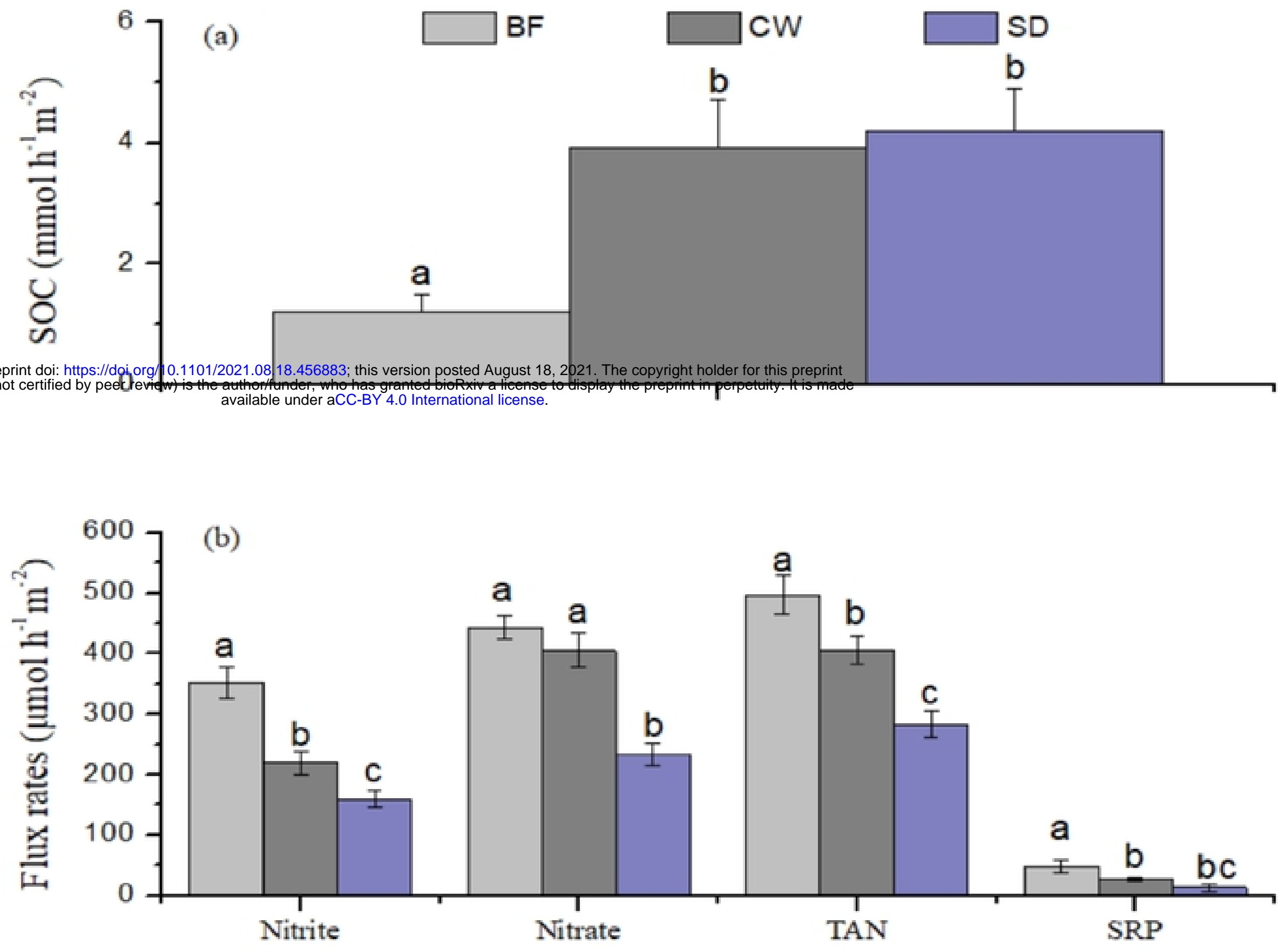

3

4

[Fig 1]

5

6 
(A)

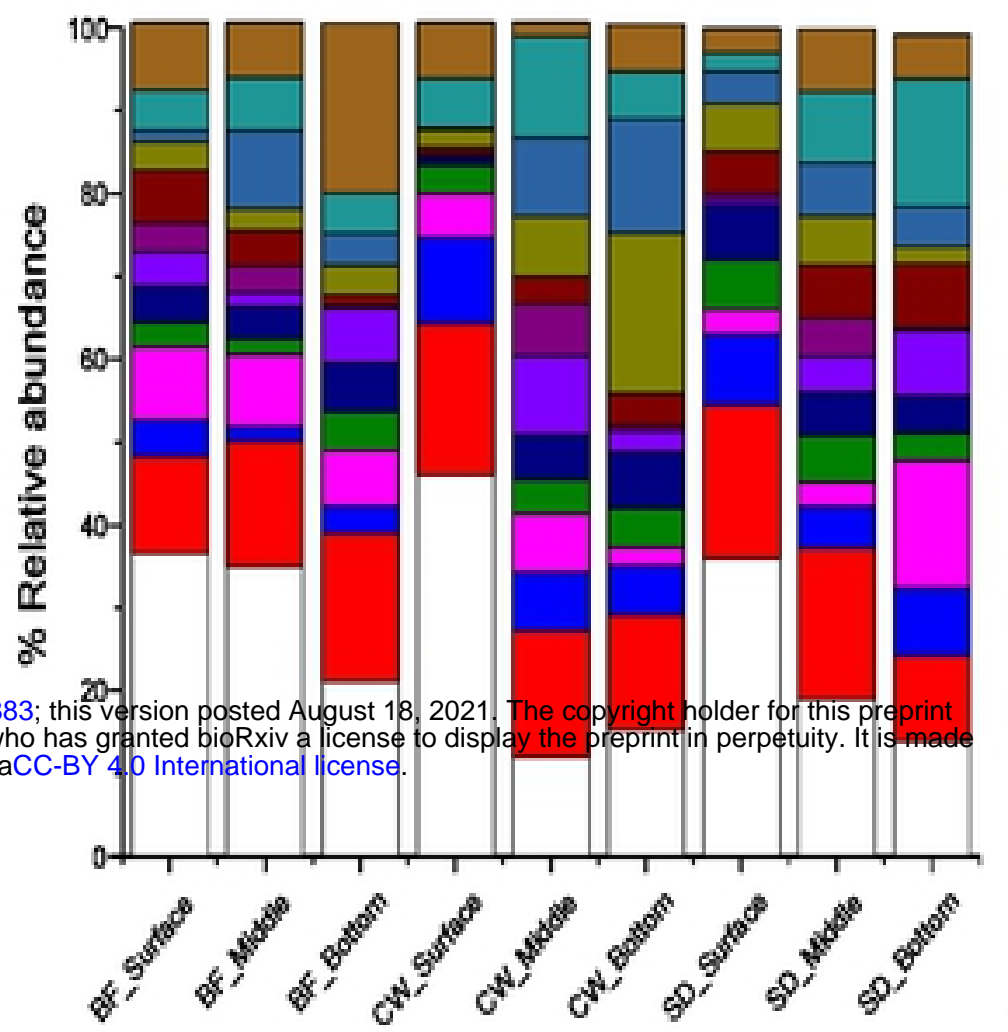

(B)

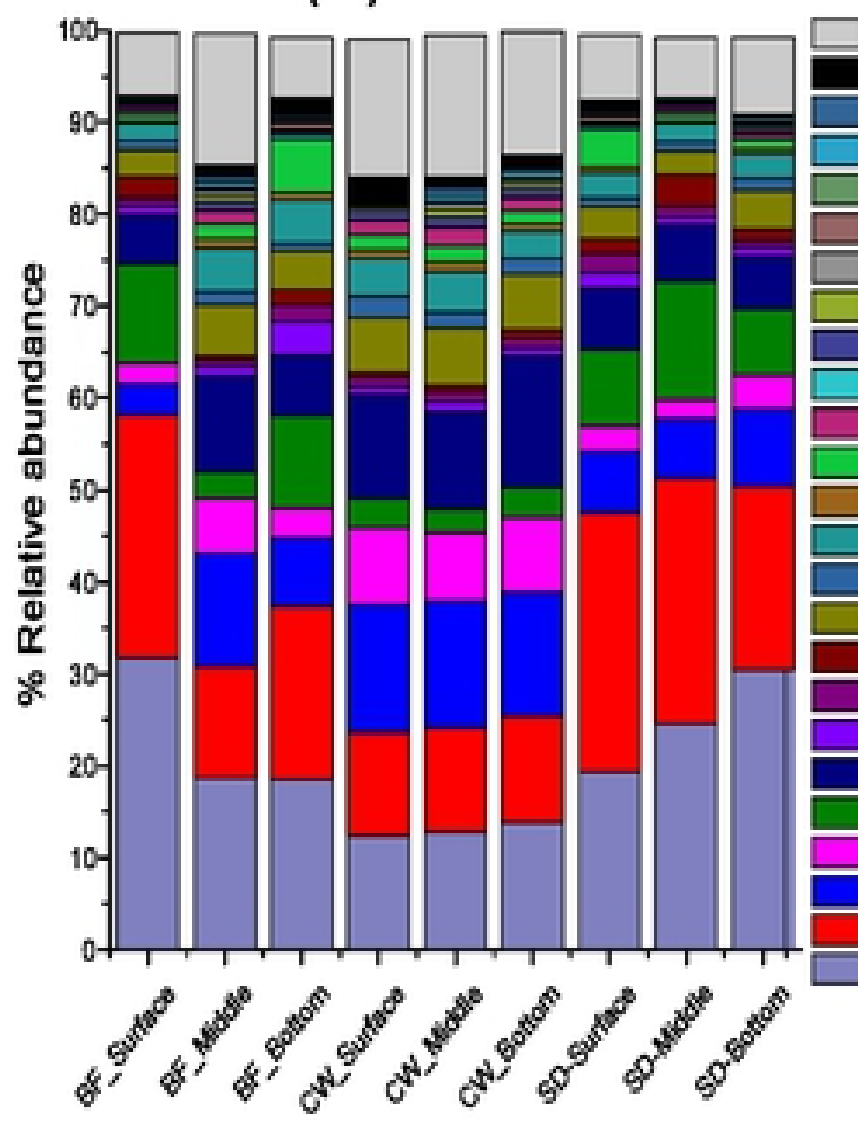

(C) 


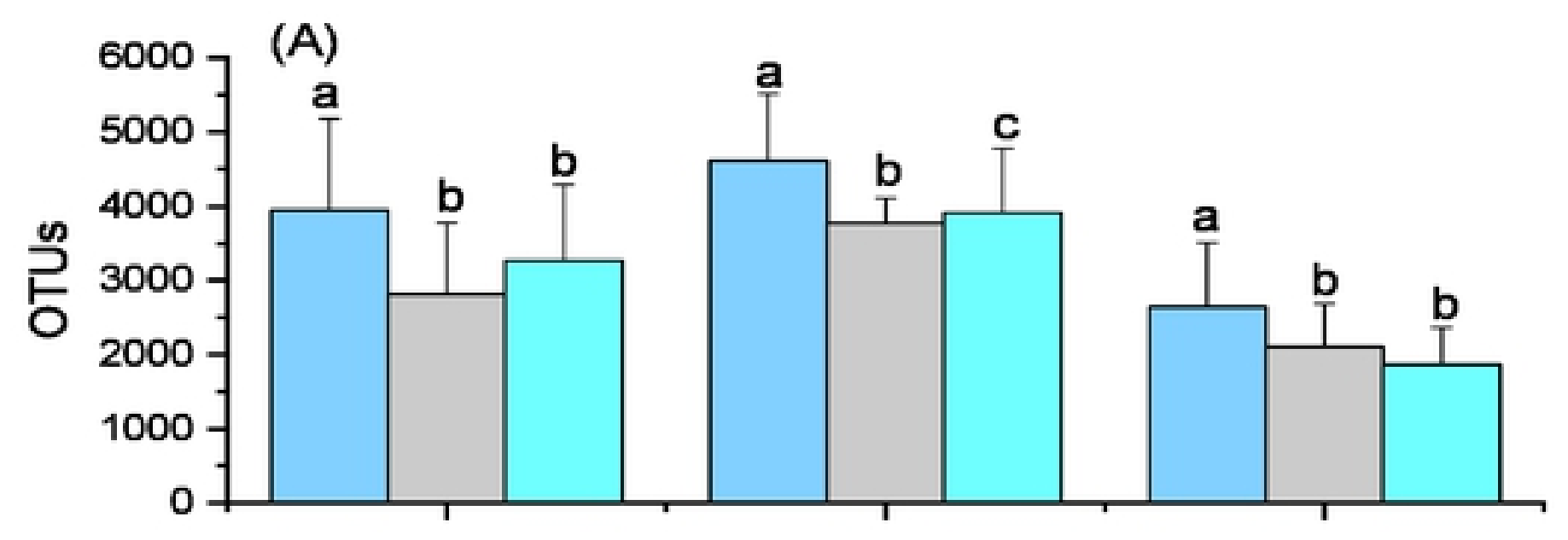

14000 (B)

$12000-\frac{a}{1}$

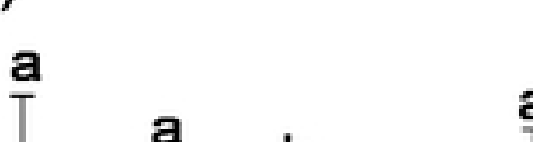

a

bioRxiv preprint doi: https://doi.org/10.1101/2829.88.98.4568\%3; thisversion p@sted Augtht 18, 2021. The copyright holder for this preprint (which was not certified by peer realebunder aCC-BY 4.0 International license.

옹

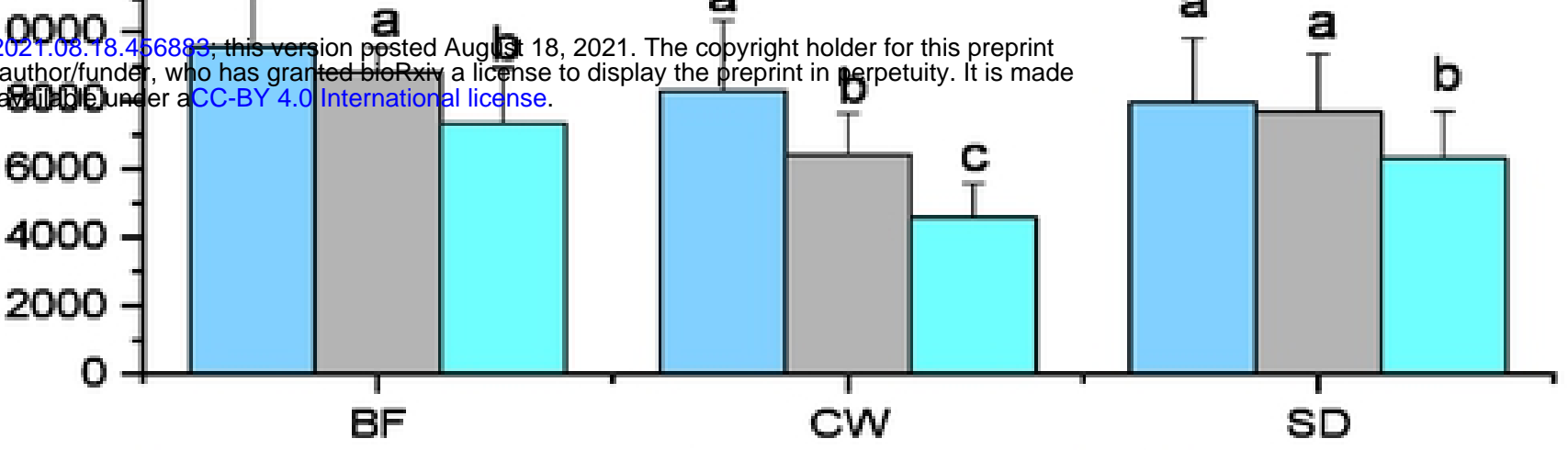

12
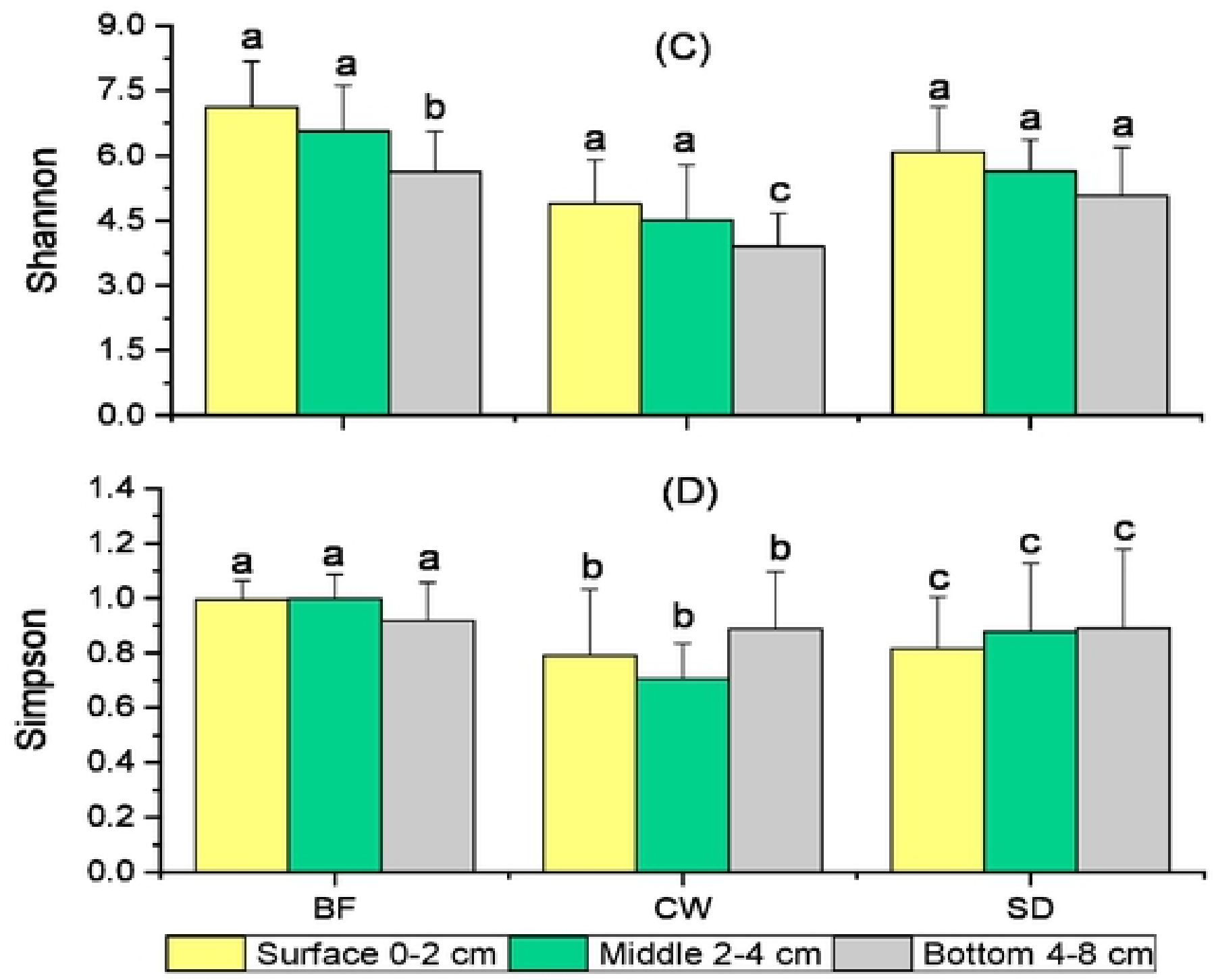

[Fig 3] 


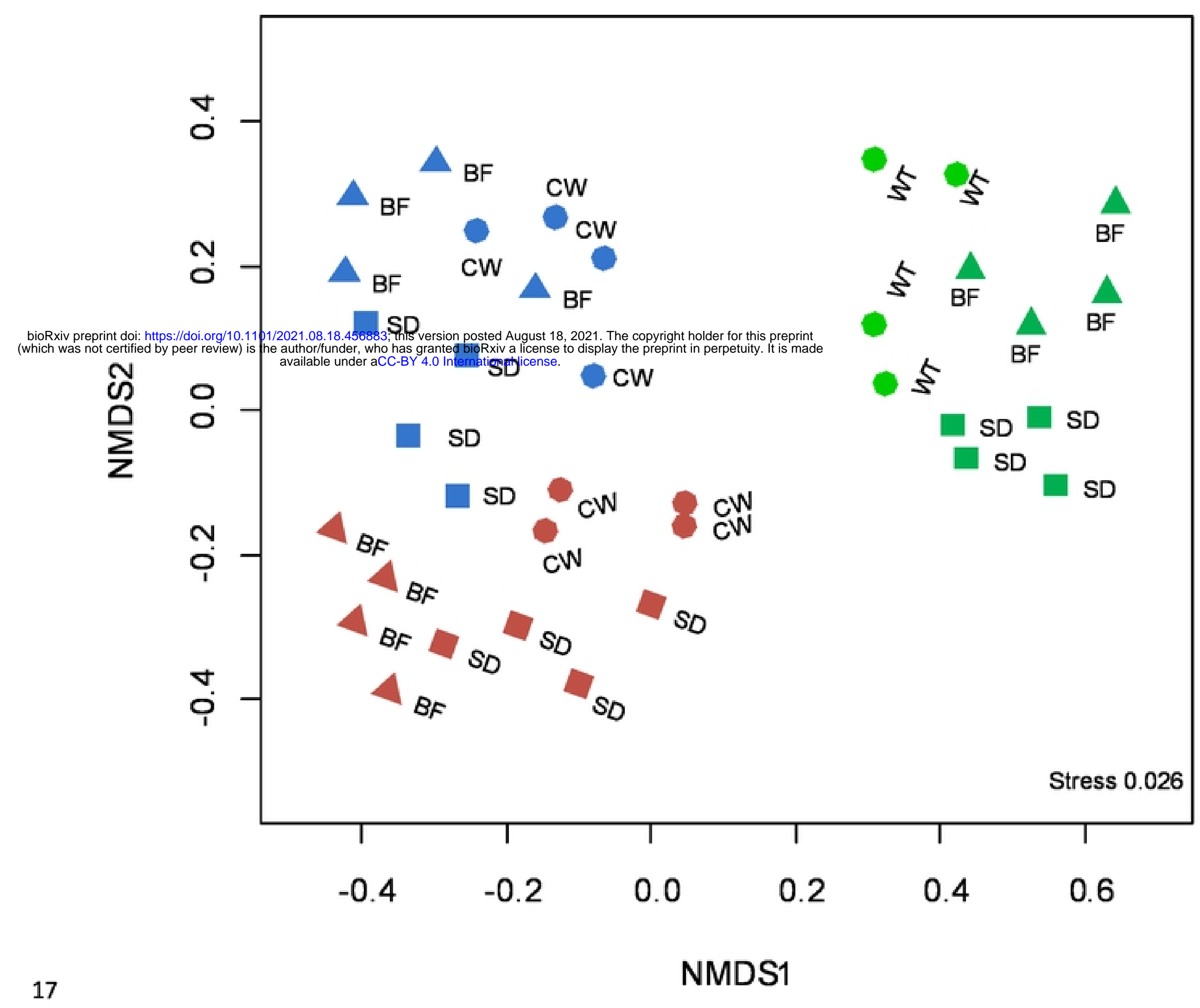




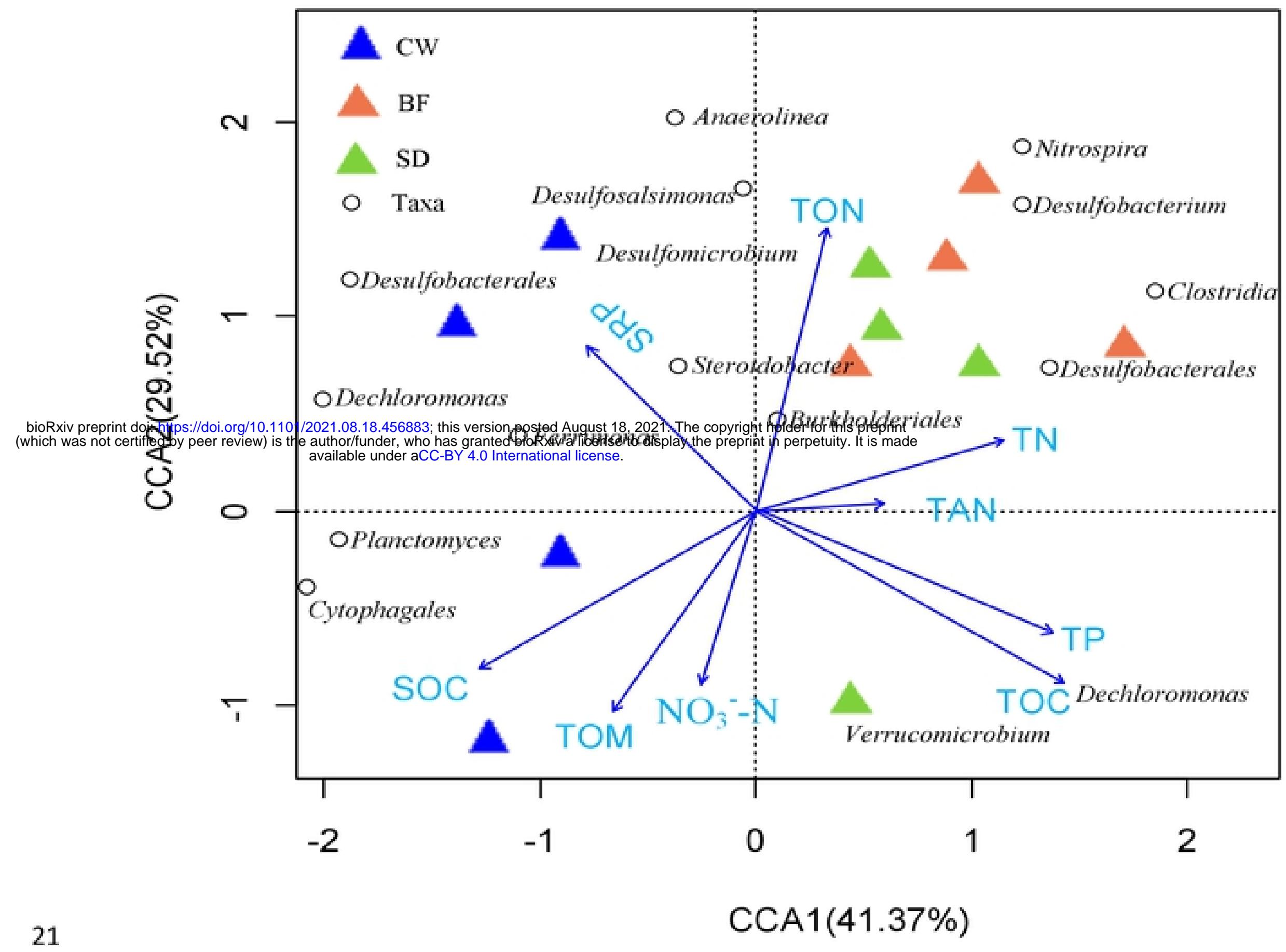

22

[Fig 5]

23

24 


$\square$ BF $\square$ CW $\square$ SD

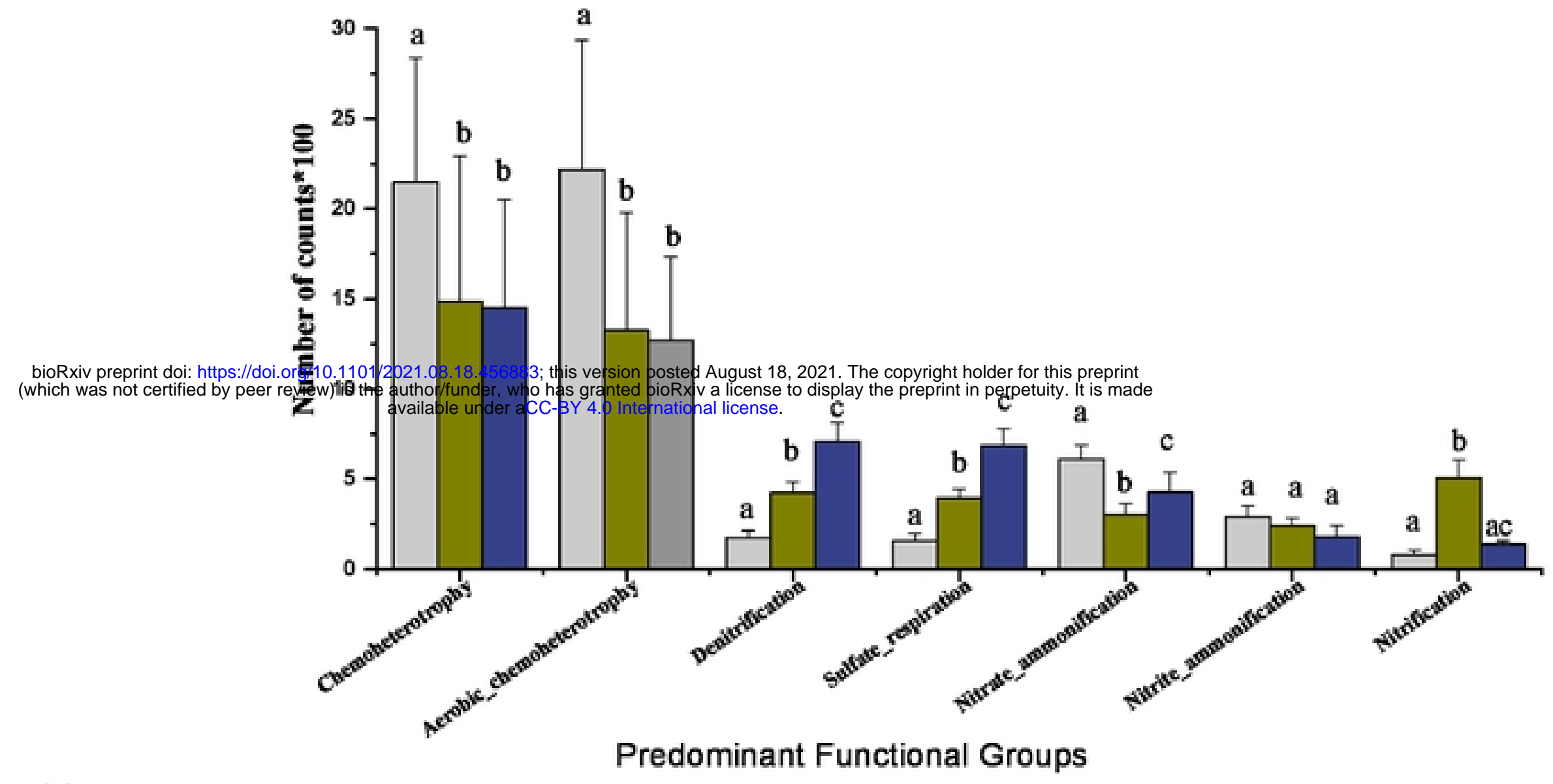

26

27

[Fig 6]

28 